A

\title{
In your opinion
}

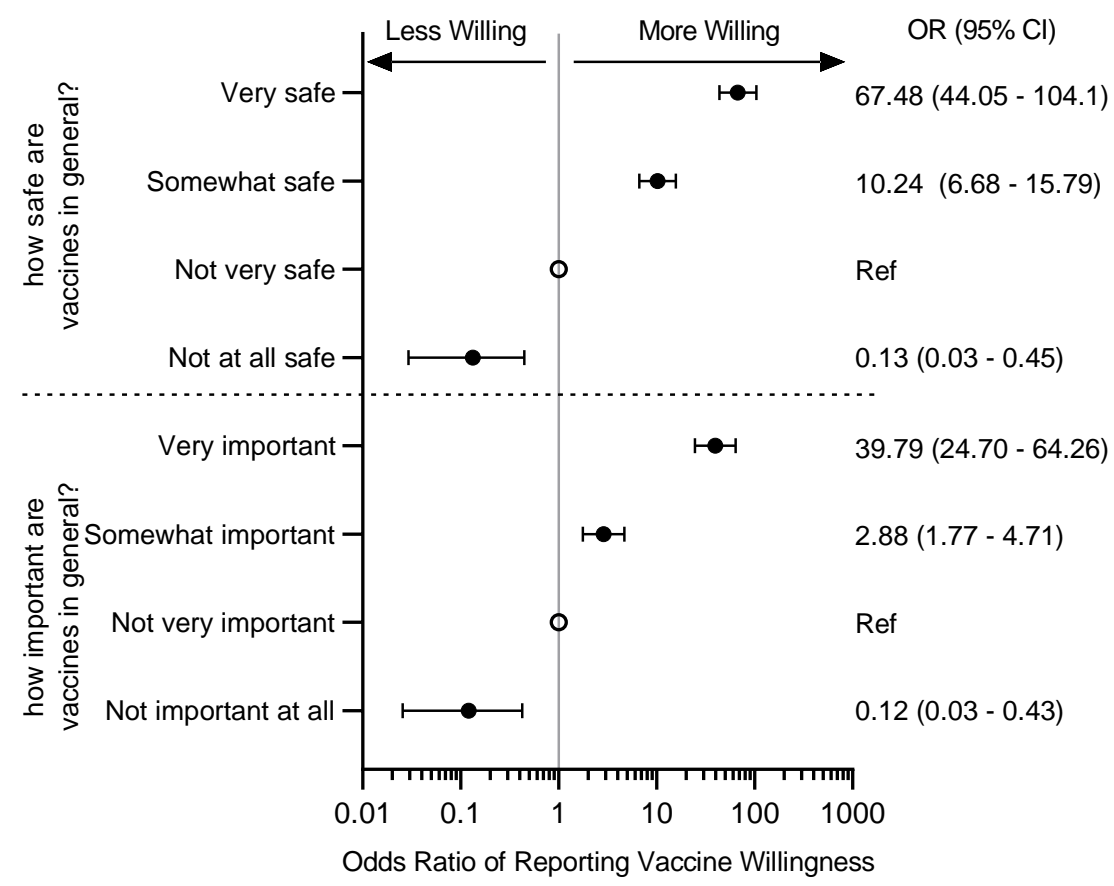

B

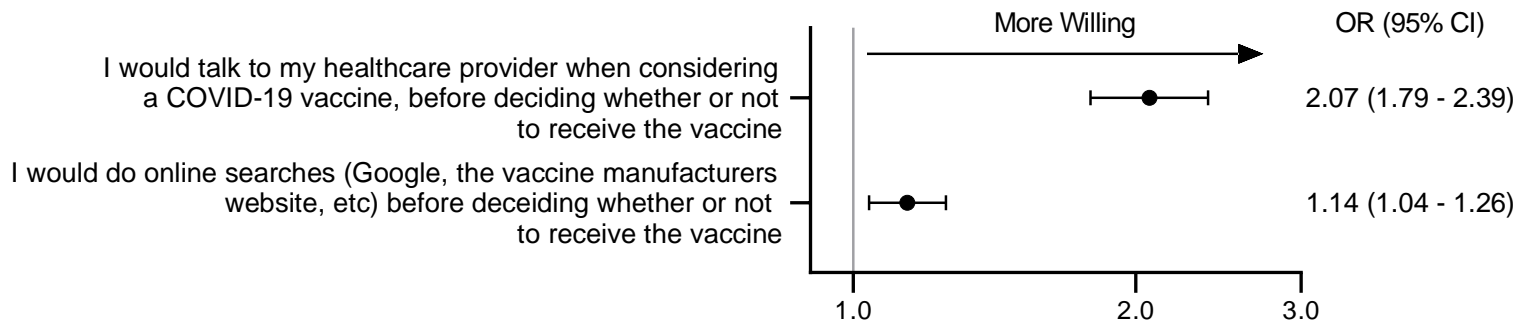

Odds Ratio of Reporting Vaccine Willingness 